\title{
Prevalence and anatomical sites of human papillomavirus, Epstein-Barr virus and herpes simplex virus infections in men who have sex with men, Khon Kaen, Thailand
}

Jureeporn Chuerduangphui ${ }^{1,5}$, Kanisara Proyrungroj ${ }^{1,5}$, Chamsai Pientong ${ }^{1,5}$, Saowarop Hinkan ${ }^{1,5}$, Jiratha Budkaew ${ }^{2}$, Charinya Pimson ${ }^{3,5}$, Bandit Chumworathayi ${ }^{4,5}$, Ploenpit Hanond ${ }^{1}$ and Tipaya Ekalaksananan ${ }^{1,5^{*}}$

\begin{abstract}
Background: Human papillomavirus (HPV), Epstein-Barr virus (EBV) and herpes simplex virus (HSV) cause sexually transmitted diseases (STDs) that are frequently found in men who have sex with men (MSM) with human immunodeficiency viral (HIV) infection.

Methods: This study investigated the prevalence of infection and anatomical site distribution of these viruses in asymptomatic MSM. DNA, extracted from cells collected from the anorectum, oropharynx and urethra of 346 participants, was investigated for the presence of EBV, HPV and HSV using real-time PCR. Demographic data from the participants were analyzed.

Results: All three viruses were found in all sampled sites. EBV was the commonest virus, being detected in the anorectum (47.7\% of participants), oropharynx (50.6\%) and urethra (45.6\%). HPV and HSV were found in $43.9 \%$ and $2.9 \%$ of anorectum samples, $13.8 \%$ and $3.8 \%$ of oropharynx samples and $25.7 \%$ and $2 \%$ of urethra samples, respectively. HPV infection of the anorectum was significantly associated with age groups $21-30$ (odds $=3.043,95 \% \mathrm{Cl}=1.643-5.638$ and $P=0.001$ ) and $46-60$ years (odds $=2.679,95 \% \mathrm{Cl}=1.406-5.101$ and $P=0.03$ ). EBV infection of the urethra was significantly correlated with age group 21-30 years (odds $=1.790,95 \% \mathrm{Cl}=1.010-3.173$ and $P=0.046$ ). EBV/HPV co-infection of the anorectum (odds $=3.211,95 \% \mathrm{Cl}=1.271-8.110, P=0.014$ ) and urethra (odds $=2.816,95 \% \mathrm{Cl}=1.024-7.740, P=0.045$ ) was also associated with this age group. Among HIV-positive MSM, there was a significant association between age-group (odds $=21.000,95 \% \mathrm{Cl}=1.777-248.103, P=0.016$ ) in HPV infection of the anorectum. A failure to use condoms was significantly associated with HPV infection of the anorectum (odds $=4.095,95 \% \mathrm{Cl}=1.404-11.943, P=0.010$ ) and urethra (odds $=7.187,95 \% \mathrm{Cl}=1.385-37.306, P=0.019$ ). Similarly, lack of condom use was significantly associated with EBV infection of the urethra (odds $=7.368,95 \% \mathrm{Cl}=1.580-34.371, P=0.011$ ).
\end{abstract}

Conclusion: These results indicate that asymptomatic MSM in Northeast Thailand form a potential reservoir for transmission of STDs, and in particular for these viruses.

Keywords: Human papillomavirus, Herpes simplex virus, Epstein-Barr virus, Co-infection, Asymptomatic MSM, Anatomical site

\footnotetext{
* Correspondence: tipeka@kku.ac.th

'Department of Microbiology, Faculty of Medicine, Khon Kaen University,

Khon Kaen, Thailand

${ }^{5} \mathrm{HPV} \&$ EBV and Carcinogenesis Research Group, Khon Kaen University, Khon

Kaen, Thailand

Full list of author information is available at the end of the article
}

(c) The Author(s). 2018 Open Access This article is distributed under the terms of the Creative Commons Attribution 4.0 International License (http://creativecommons.org/licenses/by/4.0/), which permits unrestricted use, distribution, and reproduction in any medium, provided you give appropriate credit to the original author(s) and the source, provide a link to the Creative Commons license, and indicate if changes were made. The Creative Commons Public Domain Dedication waiver (http://creativecommons.org/publicdomain/zero/1.0/) applies to the data made available in this article, unless otherwise stated. 


\section{Background}

Men who have sex with men (MSM) are at higher risk of sexually transmitted diseases (STDs) than other groups. Incidence has been rising due to the practice of various sexual acts including penile-anal, oral-anal, and/or penile-oral contact $[1,2]$. HPV is the most common sexually transmitted viral infection and its prevalence is increasing [3]. Human papillomavirus (HPV) is a causative agent of genital warts [4] and the main risk factor for anal cancer in MSM [5]. The incidence of anal cancer is highest in HIV-infected MSM and is increasing annually. HPV is also associated with oropharyngeal and penile cancers, but at lower prevalence than anal cancer [6]. Detection of HPV infection in asymptomatic MSM can be used to monitor and follow-up HPV-persistent infection for HPV-related cancer intervention.

Other viruses are also found in MSM. Epstein-Barr virus (EBV) is one of the most common human viruses found in B-cells and epithelial cells of healthy persons [7]. The presence of EBV in sites such as the anus, oropharynx and urethra can be due not only to intimate contact but also to the movement of EBV-infected B-cells. Most people are infected in childhood and do not develop symptoms, or have very minor symptoms such as a mild infectious mononucleosis syndrome [8]. EBV has been frequently found in the non-genital and genital mucosa, ulcers and urethral discharges and associated with various malignancies including Burkitt's lymphoma, Hodgkin's disease, non-Hodgkin's lymphoma, nasopharyngeal carcinoma, breast cancer, gastric cancer, etc. [9]. It seems likely to be a co-factor in $\mathrm{HPV}$-associated cancers such as anal and penile cancers $[10,11]$. Moreover, EBV infection is associated with HPV integration into the host genome, which is a relevant process in cervical cancer progression [12]. In contrast, EBV is more frequently found than HPV in oropharyngeal cancer [13, 14]. Interestingly, the prevalence of EBV in isolated B-cells of MSM is significantly higher than in heterosexual men [15]. MSM appear to be at more risk of EBV infection. Although EBV causes various types of disease, including cancer, its co-prevalence with HPV among asymptomatic MSM at various anatomical sites has been little studied.

Herpes simplex virus (HSV) is one of the commonest sexually transmitted viral infections worldwide. The usual sites of HSV infection are skin and mucosal membranes. Primary infection sites of HSV-1 and HSV-2 are the oropharynx and genital tract, respectively. Infection is often asymptomatic. Even though HSV-2 is predominantly spread via the genital route (in contrast to HSV-1) and its seroprevalence is higher in HIV-positive (> 80\%) than HIV-negative MSM [16], HSV-1 is causing an increasing proportion of anogenital herpes worldwide [17, 18]. Anogenital HSV-1 is more common in MSM than heterosexual individuals [19]. Interestingly, HSV infection is associated with increased viral load of HIV in infected MSM [20]. Interestingly, co-infection of HSV and HPV16 in patients with head and neck carcinomas (HNSCC) has the worst disease outcome [21]. In addition, HSV-1 infection may modulate the radiation resistance of HPV16-positive HNSCC cells by improving cell survival after irradiation [22]. Therefore, HSV can be a co-factor of HPV-associated carcinogenesis and may be a main reservoir in MSM. We, therefore, investigated HSV in MSM.

To explore the prevalence and anatomical site distribution of HPV, EBV and HSV infecting asymptomatic MSM in Northeast Thailand, real-time polymerase chain reaction (RT-PCR) was used to detect these viruses from 346 participants at anatomical sites including the oropharynx, urethra and anorectum.

\section{Methods}

\section{Specimen and data collection}

In total, 358 asymptomatic MSM were enrolled under a cross-sectional study project title of "Factors associated to Neisseria gonorrhea infection by anatomic distributions among men who have sex with men, and multidrug resistant patterns of Neisseria gonorrhea" at M-Reach STDs clinic in Chatapadung Contracting Medical Unit, and the ARV Clinic, Khon Kaen Hospital, Khon Kaen Province, Thailand from September 2014 to July 2015. Prevalence of Neisseria gonorrhea in urethra was published [23, 24], but not in oropharynx and anorectum. Cell samples from anorectum, oropharynx and urethra were collected using sterile Dacron swabs (Puritan, Hardwood Products, Guilford, USA). These swabs were immediately transferred into $2 \mathrm{ml}$ of $10 \%$ formalin in normal saline solution and transported to laboratory on ice within $4 \mathrm{~h}$. Three-hundred and forty-six asymptomatic MSM were included whereas 12 MSM were excluded because samples were not collected from all three anatomical sites. Participants provided basic demographic data and information concerning their sexual behavior, including number of sexual partners in the preceding 3 months, condom usage and HIV status. This was done by means of a self-reported questionnaire and data were recorded in an anonymous electronic file. The ethical approval for this study was obtained from Khon Kaen University Ethics Committee in Human Research, No. HE591377.

\section{DNA extraction}

Cells from swab samples were pelleted and washed with phosphate buffered saline by centrifugation at $2000 \mathrm{rpm}$ for $5 \mathrm{~min}$. Cells were lysed using lysis buffer $(10 \mathrm{mM}$ Tris $\mathrm{HCl}, 0.1 \mathrm{mM}$ EDTA pH 7.5, 1\% SDS and $0.5 \mathrm{M}$ $\mathrm{NaCl}$ ) supplemented with $50 \mathrm{mg} / \mathrm{ml}$ of proteinase $\mathrm{K}$ and 
then incubated at $60{ }^{\circ} \mathrm{C}$ for $30 \mathrm{~min}$. Protein was precipitated by addition of protein precipitation buffer $(5 \mathrm{M}$ potassium acetate, $11.5 \mathrm{ml}$ of glacial acetic acid and $28.5 \mathrm{ml}$ of distill water, $\mathrm{pH} 5.5$ ), and then removed by centrifugation at $13,500 \mathrm{rpm}$ for $5 \mathrm{~min}$ at $4{ }^{\circ} \mathrm{C}$. DNA was precipitated with an equal volume of isopropanol and collected by centrifugation at 13,500 rpm for $5 \mathrm{~min}$ at $25{ }^{\circ} \mathrm{C}$ and washed with $70 \%$ ethanol. Finally, the DNA pellet was dried at $37{ }^{\circ} \mathrm{C}$ for $15-30 \mathrm{~min}$ and then resuspended in distilled water. The quality of DNA was checked by amplifying the GAPDH gene using specific primers (GAPDH forward: 5'-TCATCAGCAATGCC TCCTGCA-3' and reverse: TGGGTGGCAGTGAT GGCA-3' by RT-PCR. Quantity of DNA was assessed using the NanoDrop ${ }^{\text {TM }}$ (Thermo Scientific) [25].

\section{Detection of HPV, HSV and EBV infection by RT-PCR}

HPV infection was investigated using GP5+/GP6+ primers (forward: 5' ${ }^{\prime}$ TTTGTTACTGTGGTAGATA CTAC-3' and reverse: $5^{\prime}$-GAAAAATAAACTGTAAATC ATATTC-3') by RT-PCR [26] to amplify a 141 bp portion of the L1 viral capsid gene. The reaction mixture had a final volume of $20 \mu \mathrm{l}$ containing $1 \times$ SsoAdvancedTM Universal SYBR $^{\circ}$ Green Supermix (Bio-Rad, Hercules, CA, USA), $0.2 \mu \mathrm{M}$ of forward primer, $0.2 \mu \mathrm{M}$ of reverse primer and DNA template. Thermocycling conditions were a denaturation step of $5 \mathrm{~min}$ at $95{ }^{\circ} \mathrm{C}$ followed by 45 cycles of $95{ }^{\circ} \mathrm{C}$ for $10 \mathrm{~s}$ and $42{ }^{\circ} \mathrm{C}$ for $30 \mathrm{~s}$ in an Applied Biosystems 7500 Fast real-time PCR Instrument (Applied Biosystems, Foster City, CA, USA). DNA from SiHa cells (an HPV16-positive cell line) was used as the positive control for HPV DNA detection.

HSV infection was detected using specific primers: HSV DNA polymerase forward: 5'- GTGTTGTGC CGCGGTCTCAC-3' and reverse: 5'-GGTGAACGT CTTTTCGAACTC-3'. EBV was detected using EBV DNA polymerase forward: 5'- GGAGAAGGTCTTCT CGGCCTC-3' and reverse: 5'-TTCAGAGAGCGAGA CCCTGC-3' $[27,28]$. The reaction mixture had a final volume of $20 \mu \mathrm{l}$ containing $1 \times$ SsoAdvancedTM Universal SYBR ${ }^{\circ}$ Green Supermix (Bio-Rad, Hercules, CA, USA), $0.2 \mu \mathrm{M}$ of forward primer, $0.2 \mu \mathrm{M}$ of reverse primer and DNA template. The reaction was performed in an Applied Biosystems 7500 Fast real-time PCR Instrument $(\mathrm{ABi})$. Cycling conditions were; initial $3 \mathrm{~min}$ at $95{ }^{\circ} \mathrm{C}$ followed by 40 cycles of $95{ }^{\circ} \mathrm{C}$ for $10 \mathrm{~s}, 64{ }^{\circ} \mathrm{C}$ for $10 \mathrm{~s}$ and $72{ }^{\circ} \mathrm{C}$ for $30 \mathrm{~s}$. DNA from HSV-1 kos particles and P3HR1 cells (an EBV-positive cell line) was used as the positive control for HSV DNA and EBV DNA detection, respectively.

\section{HPV genotyping}

HPV L1 gene fragments in HPV-positive samples were amplified using GP5/ GP6+ primers labeled with biotin and genotyped by reverse line blot hybridization (RLBH) [29]. Biodyne $\mathrm{C}$ blotting membrane (Pall Life Science, Ann Arbor, MI, USA) was activated in $16 \%(w / v)$ 1-ethy-3-(3-dimethylaminopropyl) carbodimide (EDAC) solution (Sigma-Aldrich, St. Louis, MO, USA) at room temperature for $10 \mathrm{~min}$, rinsed with distilled water and placed on a mini blotter. Thirty-seven HPV type-specific 5 '-amino linked oligonucleotide probes, including 13 high-risk HPV types $(16,18,31,33,35,39,45,51,52$, 56, 58, 59 and 68); 12 low-risk HPV types $(6,11,26,40,42,43$, 44, 53, 54, 61, 72 and 73); and other HPV types (34, 55, 57, 66, 70, 82MM4, 83MM7, 84MM8, 82IS39, CР6108, $71 \mathrm{CP} 8061$ and 81CP8304), were dropped onto the Biodyne $\mathrm{C}$ membrane through the wells of the mini blotter in parallel lines. Subsequently, biotin-labeled PCR products were added into the channels of the mini blotter perpendicular to the oligonucleotide probe lines, then hybridized and incubated with streptavidin-peroxidase-conjugate. The HPV types present were detected using chemiluminescence.

\section{Statistical analysis}

Bivariate analysis (for comparisons of proportions) was used to investigate the association between EBV, HPV and/or HSV infection and age, number of sex partners, condom usage and HIV status of participants using SPSS software (SPSS Inc., Chicago, IL, USA). Any $P$-value $<0.05$ was considered statistically significant.

\section{Results}

\section{Patient characteristics}

Table 1 shows demographic data and sexual behavior characteristics of 346 asymptomatic MSM participants. The age range was $18-60$ years, with the mode being the 21-30-year-old group. Most participants had only one sexual partner, or no partners, in the previous 3 months and always used condoms. A total of 234 asymptomatic MSM self-revealed HIV status.

\section{Prevalence of EBV, HPV or HSV infecting MSM and anatomical site distribution}

Swab samples were obtained from each anatomical site (anorectum, oropharynx and urethra) of 346 asymptomatic MSM participants. HPV, EBV and HSV infection were detected in all three anatomical sites (Fig. 1). EBV infection was common at all three sites, with approximately $50 \%$ of samples returning a positive result from each (Fig. 1). The anorectum was the site where HPV infection was most common (43.9\%), followed by the urethra (25.7\%) and oropharynx (13.9\%). HSV was the least prevalent (Fig. 1).

The prevalence of high-risk HPV types were higher than of low-risk HPV in all anatomical sites (Fig. 2). Double/multiple infections of high and low-risk types were particularly frequent in the anorectum (Fig. 2a), 
Table 1 Clinical data of MSM $(n=346)$

\begin{tabular}{ll}
\hline Clinical finding & $\mathrm{n}=346$ \\
\hline Age (years) & 60 \\
Minimum $=18$ & 1 \\
Maximum $=60$ & \\
Age-range groups & 76 \\
$18-20$ & 139 \\
$21-30$ & 106 \\
$31-45$ & 25 \\
$46-60$ & \\
Number of partners within 3 months & 129 \\
None & 166 \\
$1-2$ & 51 \\
$>2$ & \\
Condom usage & 223 \\
Always & 64 \\
Sometimes & 59 \\
Never & \\
HIV status & 124 \\
Negative & 110 \\
Positive & 112 \\
Unknown &
\end{tabular}

followed by the urethra (Fig. 2c), but a combination of risk types did not occur in the oropharynx (Fig. 2b). The anorectal site seems to be the main reservoir of infection of HPV high- and low-risk types in MSM.

The highest prevalence of double or multiple infections of any type of HPV was in the anorectum (67/152, $44.1 \%)$ followed by the urethra $(21 / 89,23.6 \%)$ and oropharynx $(3 / 48,6.3 \%)$. Infections with double and multiple HPV types were more common than with single HPV types in the anorectum (44.1\% vs. $40.1 \%$, with HPV types 18 and 58 being the most common combination), but not in the oropharynx $(6.3 \%$ vs. $52.1 \%$, with HPV types 39 and 58 being the most common combination) or urethra (23.6\% vs. $57.3 \%$, with HPV types 16 and 18 being the most common combination) (Additional file 1: Table S1). HPV 18 was mostly found in the anorectum (42/152, 27.6\% followed by HPV 16 and HPV 58 in similar proportions at 25\%) and in the urethra (40/89, 44.9\% followed by HPV 16 and HPV 58 in $21.3 \%$ and 19.1\% respectively). HPV 58 was most frequently detected in the oropharynx (18/48, 37.5\% followed by HPV types 39,18 and 53 at $8.3 \%, 6.3 \%$ and $6.3 \%$ respectively).

Factors associated with prevalence of HPV, EBV and HSV in the anorectum, oropharynx and urethra among 346 asymptomatic MSM

There were often significant differences between age groups in prevalence and anatomical sites, as shown in Table 2. EBV infection in the urethra (but not the anorectum or oropharynx) was significantly associated with the $21-30$ years-old group (odds $=1.790,95 \% \mathrm{CI}=$ 1.010-3.173 and $P=0.046)$. HPV infection in the anorectum was significantly associated with the 2130 years-old group (odds $=3.043,95 \% \mathrm{CI}=1.643-5.638$ and $P=0.001$ ) and also the 46-60 years-old group (odds $=2.679,95 \% \mathrm{CI}=1.406-5.101$ and $P=0.03)$. HSV infection in the oropharynx was mostly found in the 4660 years-old group. EBV infection in the oropharynx and urethra was significantly higher among HIV-positive MSM than among HIV-negative MSM (odds $=2.125$, 95\% $\mathrm{CI}=1.257-3.594$ and $P=0.005$ and odds $=2.536$, 95\% CI $=1.496-4.298$ and $P=0.001$, respectively). Likewise, HPV infection in the anorectum was significantly associated with HIV-infected MSM (odds $=1.935$, 95\% $\mathrm{CI}=1.150-3.257$ and $P=0.013)$. In contrast, the incidence of HSV did not differ according to HIV status. This result suggested that HIV-infected MSM might act as reservoirs for transmission of EBV and HPV.

Table 3 shows the correlation between HPV and EBV infection in HIV-infected and uninfected MSM with the associated factors. HPV infection in the anorectum in HIV-positive MSM was significantly associated with increasing age. For the 31-45 years-old group, odds = 10.500, 95\% CI $=1.177-93.697, P=0.035$; and for the $46-60$ years-old group, odds $=21.000,95 \% \mathrm{CI}=1.777-$ 248.103, $P=0.016$. Co-infection of HIV with HPV-infected anorectum (odds $=4.095$, 95\% CI $=1.404-$ 11.943 and $P=0.010$ ), urethra (odds $=7.187,95 \% \mathrm{CI}=$ 1.385-37.306, $P=0.019$ ) or EBV-infected urethra (odds $=7.368,95 \% \mathrm{CI}=1.580-34.371, P=0.011$ ) was significantly associated with an absence of condom usage. HPV infection in the oropharynx wasn't associated with any demographic factors (data not shown). In addition, no association was found between demographic factors and EBV infection in the anorectum and oropharynx among HIV-infected and uninfected MSM (data not shown). This result demonstrated that lack of condom usage was an important factor for HPV infection in the anorectum and urethra as well as EBV infection in the urethra among HIV-positive MSM.

\section{Co-infection with EBV, HPV and/or HSV in three anatomical sites}

Co-infection with EBV and HPV was common, especially in the anorectum (17.3\%) (Fig. 3). Reflecting its low prevalence generally, co-infection of HSV with either of the other two viruses was uncommon (Fig. 3). All three viruses were found in $0.9 \%(3 / 346)$ of MSM in the anorectum or urethra but not in the oropharynx (Fig. 3). These results demonstrate that co-infection of EBV and HPV common among northeast Thai MSM at all three anatomical sites. 


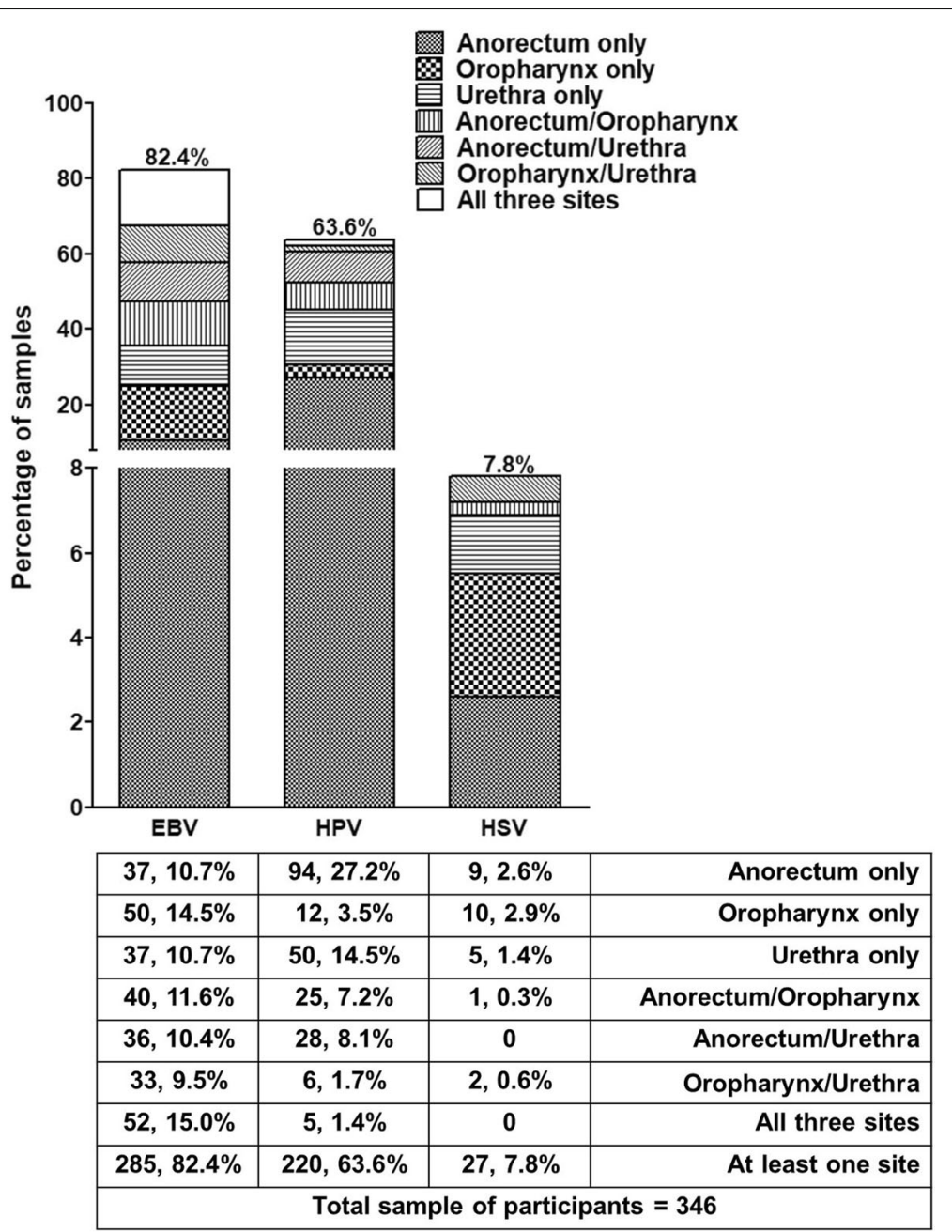

Fig. 1 Prevalence of EBV, HPV and HSV in the anorectum, oropharynx and urethra in 346 asymptomatic MSM (n, \%)

The association of demographic factors and co-infection of EBV, HPV and HSV in anorectal, oropharyngeal and urethal sites among asymptomatic MSM

Co-infection of HPV with EBV or HSV in all three anatomical sites has not been reported previously. We investigated the association of EBV, HPV and/or HSV co-infection in anorectal, oropharyngeal or urethral sites with demographic factors. Interestingly, co-infection with EBV and HPV at both the anorectum and urethra was significantly associated with the 21-30 years-old group $\quad$ odds $=3.211, \quad 95 \% \quad \mathrm{CI}=1.271-8.110, \quad P=0.014$ and odds $=2.816,95 \% \mathrm{CI}=1.024-7.740, P=0.045$ respectively), as shown in Additional file 2: Tables S2 and Additional file 3: Tables S3. In addition, EBV and HPV co-infection in the anorectum and urethra was most found frequently in MSM with current or recent partners and in HIV-positive MSM. Meanwhile, EBV and HPV co-infection at the oropharyngeal site was most frequent in the 45-60 years-old group, as well as in HIV-positive MSM (Additional file 4: Table S4).
Co-infections of EBV with HSV, and of HPV with HSV, and of all three viruses together, were not associated with any demographic factors in any anatomical sites (Additional file 2: Tables S2, Additional file 3: Table S3, and Additional file 4: Tables S4). These findings show that co-infection of EBV with HPV was predominately found in the 21-30 years-old group in the anorectum and urethra but not in the oropharynx.

\section{Discussion}

In this study, we addressed the prevalence of HPV, EBV and HSV as single and co-infections in different anatomical sites (anorectum, oropharynx and urethra) of 346 MSM in Northeast Thailand. Demographic information was collected from participants, and especially HIV status. Several previous reports exist about the prevalence of EBV in the same anatomical sites of MSM from other countries. EBV infection was found in the anorectum of 29.6\% and 32\% of HIV-positive German and Swedish MSM, respectively [30, 31]. Oropharyngeal shedding of 


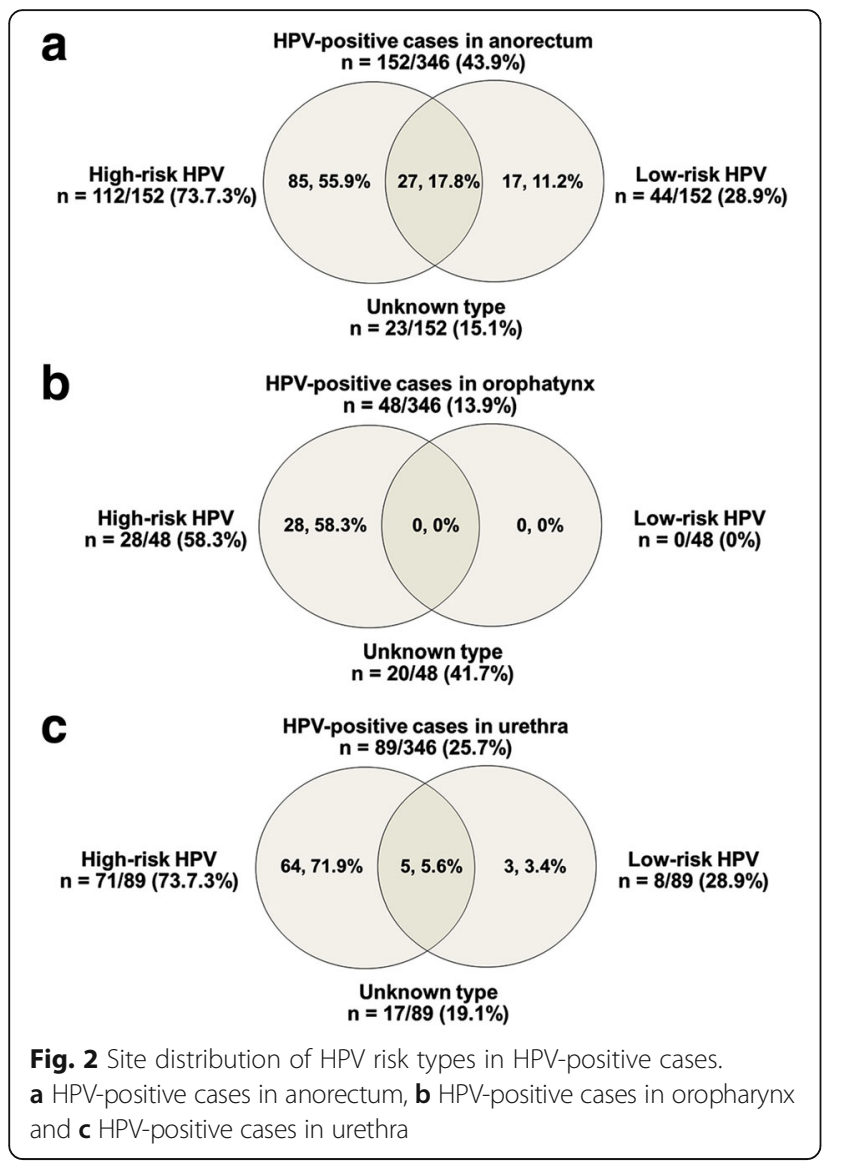

EBV was detected in $49-88.8 \%$ and $16-56 \%$ of HIV-seropositive and seronegative MSM, respectively $[32,33]$. In the urethral site, EBV was found in $30.7 \%$ of asymptomatic American MSM; notably, EBV prevalence (72.7\%) was significantly associated with HIV shedding in semen [34], corresponding to our finding as shown in Table 2. EBV infection of the urethra ranged from 28 to 30.7\% among American MSM [34, 35]. Meanwhile, EBV infection of the urethra of American and Spanish men was ranged from $0.4-45 \%$ [36]. Most of these published articles demonstrated that EBV had the highest prevalence in the oropharynx, in contrast to the anorectum and urethra, corresponding to our results.

Many studies have demonstrated a high prevalence of HPV infection in the anorectum, ranging from 34.8 to $65.3 \%$ [37-39], and was significantly associated with HIV-infected MSM [37, 38], concordant with our results. Prevalence of HPV infection were lower in the oropharynx and urethra $(9.6-13.0 \%$ and $10.2-16.3 \%$, respectively) [37, 40-42]. As is the case for the anorectum, high prevalence of HPV infection at the oropharynx and urethra were significantly associated with HIV-positive MSM [41, 42].

In Peruvian MSM, the five most common HPV genotypes from the anorectum were 53, 6, 16, 58 and 54 [43]. Similarly, HPV53 was the most frequently found genotype in anorectal samples from HIV-seropositive French MSM [44], but HPV16 was the most frequently found at

Table 2 Prevalence of EBV, HPV or HSV in age range, number of partners within 3 months, condom usage and HIV status in the anorectum, oropharynx and urethra among 346 asymptomatic MSM

\begin{tabular}{|c|c|c|c|c|c|c|c|c|c|}
\hline \multirow[t]{2}{*}{ Factors } & \multicolumn{3}{|c|}{ Anorectum, n (\%) } & \multicolumn{3}{|c|}{ Oropharynx, n (\%) } & \multicolumn{3}{|c|}{ Urethra, n (\%) } \\
\hline & EBV & HPV & HSV & EBV & HPV & HSV & EBV & HPV & HSV \\
\hline \multicolumn{10}{|l|}{ Age range (years) } \\
\hline $18-20(n=76)$ & $35(46.1)$ & $19(25.0)$ & $3(3.9)$ & $41(53.9)$ & $7(9.2)$ & 0 & $28(36.8)$ & $18(23.7)$ & $2(2.6)$ \\
\hline $21-30(n=139)$ & $68(48.9)$ & $70(50.4)^{*}$ & $3(2.2)$ & $77(55.4)$ & $25(18.0)$ & $3(2.2)$ & $71(51.1)^{*}$ & $42(30.2)$ & $2(1.4)$ \\
\hline $31-45(n=106)$ & $51(48.1)$ & $50(47.2)$ & $3(2.8)$ & $44(41.5)$ & $10(9.4)$ & $7(6.6)$ & $48(45.3)$ & $23(21.7)$ & $3(2.8)$ \\
\hline $46-60(n=25)$ & $11(44.0)$ & $13(52.0) *$ & $1(4.0)$ & $13(52.0)$ & $6(24.0)$ & $3(12.0)$ & $11(44.0)$ & $6(24.0)$ & 0 \\
\hline \multicolumn{10}{|c|}{ Number of partners within 3 months } \\
\hline None $(n=129)$ & $56(43.4)$ & $57(44.2)$ & $2(1.6)$ & $74(57.4)$ & $17(13.2)$ & $3(2.3)$ & $66(51.2)$ & $30(23.3)$ & $5(3.9)$ \\
\hline $1-2(n=166)$ & $83(50.0)$ & $78(47.0)$ & $5(3.0)$ & $78(47.0)$ & $28(16.9)$ & $8(4.8)$ & $72(43.4)$ & $45(27.1)$ & 0 \\
\hline$>2(n=51)$ & $26(51.0)$ & $17(33.3)$ & $3(5.9)$ & $23(45.1)$ & $3(5.9)$ & $2(3.9)$ & $20(39.2)$ & $14(27.5)$ & $2(3.9)$ \\
\hline \multicolumn{10}{|l|}{ Condom usage } \\
\hline Always $(n=223)$ & $10(47.1)$ & $98(43.9)$ & $7(3.1)$ & $111(49.8)$ & $30(13.5)$ & $7(3.1)$ & $97(43.5)$ & $54(24.2)$ & $5(2.2)$ \\
\hline Sometimes $(n=63)$ & $36(56.3)$ & $23(35.9)$ & $2(3.1)$ & $33(51.6)$ & $6(9.4)$ & $3(4.7)$ & $28(43.8)$ & $21(32.8)$ & $1(1.6)$ \\
\hline Never $(n=60)$ & $24(40.7)$ & $31(52.5)$ & $1(1.7)$ & $31(52.5)$ & $12(20.3)$ & $3(5.1)$ & $33(55.9)$ & $14(23.7)$ & $1(1.7)$ \\
\hline \multicolumn{10}{|l|}{ HIV status } \\
\hline Negative $(n=124)$ & $60(48.4)$ & $53(42.7)$ & $6(4.8)$ & $56(45.2)$ & $21(16.9)$ & $6(4.8)$ & $45(36.3)$ & $30(24.2)$ & $2(1.6)$ \\
\hline Positive $(n=110)$ & $53(48.2)$ & $65(59.1)^{*}$ & $4(3.6)$ & $70(63.6)^{*}$ & $16(14.5)$ & $5(4.5)$ & $65(59.1)^{*}$ & $32(29.1)$ & $3(2.7)$ \\
\hline Unknown $(n=112)$ & $52(46.4)$ & $34(30.4)$ & 0 & $49(43.8)$ & $11(9.8)$ & $2(1.8)$ & $48(42.9)$ & $27(24.1)$ & $2(1.8)$ \\
\hline
\end{tabular}

* denotes significant difference at $P<0.05$ by multivariate analysis 
Table 3 The association of demographic factors with HPV infection in the anorectum and urethra and with EBV infection in the urethra among HIV-infected MSM

\begin{tabular}{|c|c|c|c|c|c|c|}
\hline \multirow[t]{2}{*}{ Factors } & \multicolumn{2}{|c|}{ HPV-infected anorectum } & \multicolumn{2}{|c|}{ HPV-infected urethra } & \multicolumn{2}{|c|}{ EBV-infected urethra } \\
\hline & $\mathrm{HIV}+$ & Odds, 95\%Cl, $P$-value & $\mathrm{HIV}+$ & Odds, 95\%Cl, $P$-value & $\mathrm{HIV}+$ & Odds, 95\%Cl, $P$-value \\
\hline \multicolumn{7}{|l|}{ Age range (years) } \\
\hline $18-20(n=76))$ & $1(12.5)$ & Reference & $0(0)$ & - & $3(42.9)$ & Reference \\
\hline $21-30(n=139)$ & $31(53.5)$ & $8.037,0.929-69.542,0.058$ & $18(53.0)$ & Reference & $35(61.4)$ & $2.121,0.433-10.392,0.354$ \\
\hline $31-45(n=106)$ & $24(60.0)$ & $10.500,1.177-93.697,0.035$ & $9(50.0)$ & $0.889,0.283-2.789,0.840$ & $22(59.5)$ & $1.956,0.381-10.026,0.421$ \\
\hline $46-60(n=25)$ & $9(75.0)$ & $21.000,1.777-248.103,0.016$ & $5(83.3)$ & $4.444,0.468-42.175,0.194$ & $5(55.6)$ & $1.667,0.227-12.221,0.615$ \\
\hline \multicolumn{7}{|c|}{ No. of partners within 3 mouths } \\
\hline None $(n=129)$ & $30(66.7)$ & Reference & $13(68.4)$ & Reference & $28(62.2)$ & Reference \\
\hline$\geq 1(n=217)$ & $35(48.0)$ & $0.461,0.213-1.000,0.050$ & $19(44.2)$ & $0.365,0.117-1.142,0.083$ & $37(56.9)$ & $0.802,0.369-1.745,0.579$ \\
\hline \multicolumn{7}{|l|}{ Condom usage } \\
\hline Always ( $n=223$ ) & $40(50.6)$ & Reference & $16(41.0)$ & Reference & $38(52.0)$ & Reference \\
\hline Sometimes $(n=63)$ & $4(30.8)$ & $0.433,0.123-1.524,0.193$ & $6(54.5)$ & $1.725,0.448-6.637,0.428$ & $11(57.9)$ & $1.266,0.457-3.512,0.650$ \\
\hline Never $(n=60)$ & $21(80.8)$ & $4.095,1.404-11.943,0.010$ & $10(55.9)$ & $7.187,1.385-37.306,0.019$ & $16(88.0)$ & $7.368,1.580-34.371,0.011$ \\
\hline
\end{tabular}

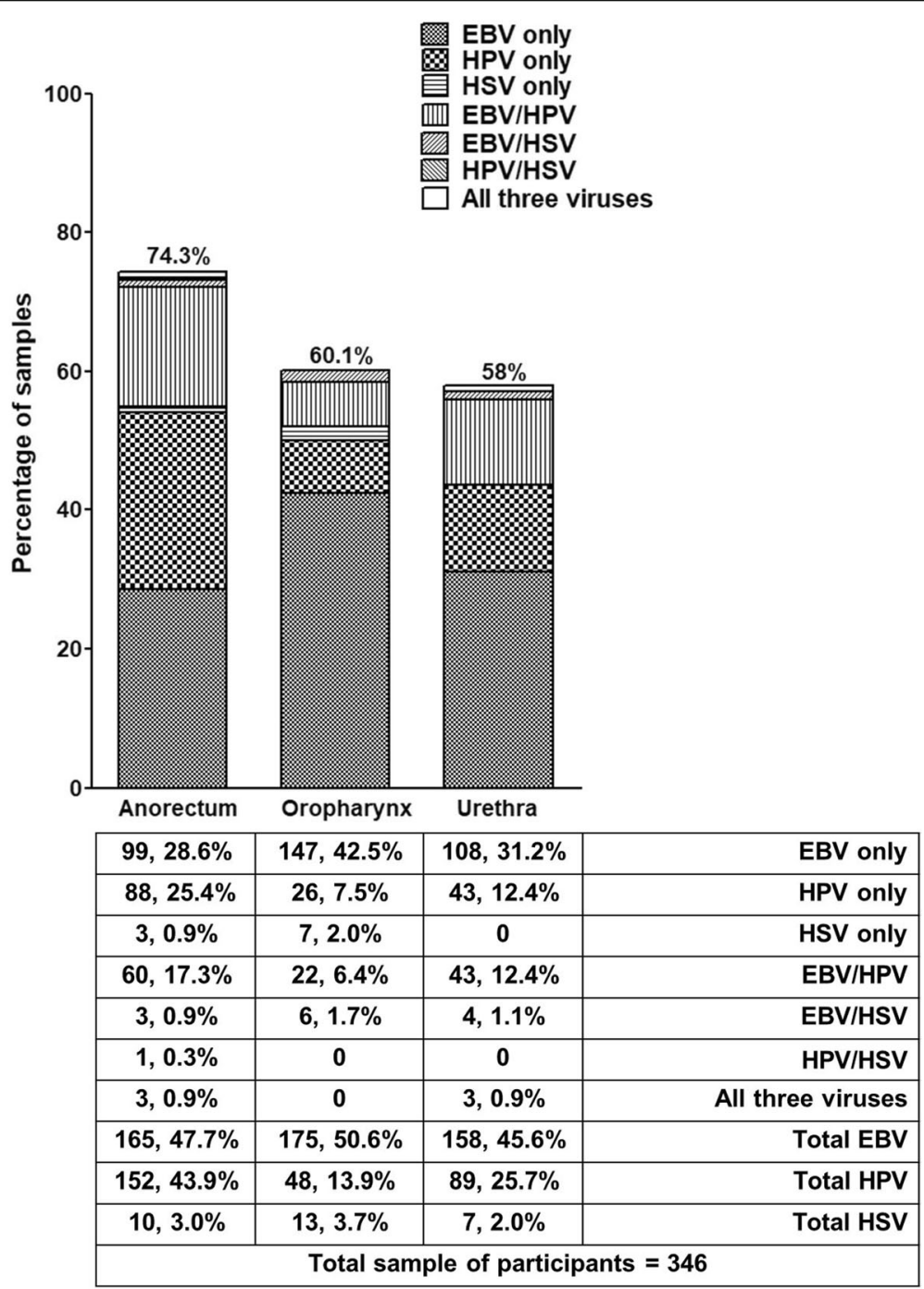

Fig. 3 Prevalence and anatomical site distribution of EBV, HPV and EBV in 346 asymptomatic MSM (n, \%) 
this site in Chinese MSM where it was not associated with HIV status. However, HPV6, 18, 31, 39, 45 and 66 were significantly associated with HIV infection in China [39]. HPV16 was the most common genotype found in the anorectum of Italian MSM [45]. However, HPV18 was the most frequently found genotype in the anorectum and urethra of Northeast Thai MSM. In the urethral site, HPV58 was the most common in Italian MSM. HPV16 and HPV58 were the most common infections of the oropharynx of MSM in The Netherlands and Italy respectively $[40,42]$. Concordantly, our study has also demonstrated the highest proportion of HPV58 in the oropharynx. Although HPV16 was the most common genotype detected in these three anatomical sites among South African and Dutch MSM [42, 46], there appears to be variation by region and nationality. Co-infections with two or more HPV genotypes are significantly more frequent than single infections [43, 44], consistent with our findings and particularly in the anorectum. Unsurprisingly, high-risk HPV has been more frequently detected than low-risk genotypes among MSM worldwide $[39,44]$.

Most studies of HSV infection in MSM have reported only seroprevalence $(82.5-90 \%)[47,48]$. However, a few studies have reported prevalence of HSV DNA in the anorectum (ranging from 7.0 to $16.9 \%$ ), oropharynx (07.2\%) and urethra (2.3-49.5\%) among MSM [11, 34, 4951]. Consistent with previous studies, we found very low prevalence of HSV in all three sites (Fig. 1).

Our report is the first to find that EBV infection is present in anorectal, oropharyngeal and urethral sites of northeast Thai MSM at higher prevalence than are HPV and HSV. A previous study found high-risk HPV at higher prevalence $(90.8 \%)$ in the anorectal canal than low-risk-HPV (73.8\%), HSV-1 (7.7\%), HSV-2 (16.9\%) and EBV (7.7\%) among HIV-positive Brazilian men [11]. This agreed with a Swedish study of anal cell samples, which found higher HPV infection (76\%) among HIV-infected and uninfected MSM than EBV (18.7\%) and HSV (9.4\%) [30].

HPV was also the most common virus found in anal swabs (44\%), followed by semen (7.1\%) and pharyngeal swabs (3.8\%) in American MSM [35], consistent with our finding that HPV infection was more frequent in the anorectum than in the urethra and oropharynx.

It is well known that HIV-infected MSM have an increased risk of sexually transmitted infections (STIs) and STDs [52]. In addition, HIV infection not only increases susceptibility to persistent HPV but also increases the risk of acquisition of new HPV infections [53]. Similarity, EBV shedding was significantly associated with persistent HPV infection among HIV-infected MSM in the USA [35]. Our finding demonstrated that the presence of HPV in the anorectum was significantly associated with HIV infection in MSM (Table 2). We also found EBV infection of the oropharynx and urethra to be significantly associated with HIV-positive MSM (Table 2). Previous studies suggested that prevalence of EBV, HPV and HSV infection were associated with HIV-infected MSM but not HIV-uninfected MSM [30].

A few studies have reported co-infection of EBV, HPV and/or HSV in asymptomatic MSM. For example, high-risk HPV/HSV-2 co-infections were present in the anorectum of $55 \%$ of Brazilian MSM. Corresponding values for other combinations in that study were $27 \%$ (high-risk HPV/low-risk HPV/EBV), 9\% (high-risk HPV/ low-risk HPV/HSV2/EBV) and 9\% (high-risk HPV/lowrisk HPV/HSV-1/HSV-2/EBV) [11]. HPV and HSV co-infections were found in $4.3 \%$ of oral samples from Finnish males [50]. We have demonstrated that co-infection of EBV with HPV was the most common in the anorectum (17.3\%), oropharynx (6.4\%) and urethra (12.4\%) and was significantly associated with the 21-30 years-old group (Fig. 3 and Additional file 2: Tables S2, Additional file 3: Table S3, and Additional file 4: Tables S4).

Different results in prevalence in anatomical sites of three viruses and in the association with any risk factors among various countries may depend on the technique used, site and equipment of sample collection, sample size, sexual behavior, nationality, geography, and particularly questionnaire pattern, etc. (such as a self-report or community based). The strength of our study is that 1 ) we used swab sample in urethra because this can increase sensitivity of Neisseria gonorrhea detection compared with urine sample [24] whereas many previous studies performed EBV, HPV and HSV detection in MSM semen [35, 36]; additionally the cell samples can indicate true infection at each anatomical site instead of movement of EBV infected B cells to each sites; and 2) all participants recruited in our study are collected cell samples from all anatomical sites to compare each participants that can reduce the error of data. However, there was a limitation in our study including self-reporting MSM that may provide invalid answers such as HIV status [54]. This limitation may cause an inaccurate data analysis of demographic information.

Here, we also investigated HIV status among EBV, HPV or HSV-positive MSM. We found that HPV infection of the anorectum increased with age among HIV-infected MSM (Table 3). In addition, failure to use condoms by HIV-positive MSM was significantly associated with HPV infection of the anorectum and urethra as well as with EBV infection of the urethra (Table 3).

\section{Conclusions}

EBV and HPV were detected in asymptomatic MSM in Northeast Thailand and were found more frequently 
than HSV in all three anatomical sites (oropharynx, anorectum and urethra). Oncogenic high-risk HPV genotypes were highly prevalent at these three sites in this population. Therefore, molecular detection and HPV genotyping may be useful for identifying these viruses and facilitating interventions to limit their spread among MSM, especially HIV-infected MSM.

\section{Additional files}

Additional file 1: Table S1. Single and double/multiple infections of different HPV types in the anorectum, oropharynx and urethra. (DOCX $15 \mathrm{~kb})(\mathrm{DOCX} 16 \mathrm{~kb})$

Additional file 2: Table S2. The association of demographic factors and co-infection of EBV, HPV and/or HSV in the anorectal site. (DOCX $16 \mathrm{~kb}$ ) (DOC $44 \mathrm{~kb}$ )

Additional file 3: Table S3. The association of demographic factors and co-infection of EBV, HPV and/or HSV in the urethral site. (DOCX 16 kb) (DOC $43 \mathrm{~kb}$ )

Additional file 4: Table S4. The association of demographic factors and co-infection of EBV, HPV and/or HSV in the oropharyngeal site. (DOCX $16 \mathrm{~kb}$ ) (DOC $45 \mathrm{~kb})$

\section{Abbreviations}

EBV: Epstein-Barr virus; HIV: human immunodeficiency virus; HNSCC: head and neck carcinomas; HPV: human papillomavirus; HSV: herpes simplex virus; MSM: Men who have sex with men; STD: sexually transmitted disease; STI: sexually transmitted infections

\section{Acknowledgements}

We would like to acknowledge Prof. David Blair, for editing the MS via Publication Clinic KKU, Thailand.

\section{Funding}

This study was granted by Faculty of Medicine, Khon Kaen University, Thailand (grant number IN59350) and received a scholarship under the PostDoctoral Training Program from Research Affairs and Graduate School, Khon Kaen University, Thailand (grant number 58443).

\section{Availability of data and materials}

The datasets used and/or analyzed during the current study are available from the corresponding author on reasonable request.

\section{Authors' contributions}

JC, KP CharP performed the experiment and analyzed the data, JC, ChamP and TE wrote the initial draft of this manuscript. $\mathrm{KP}, \mathrm{SH}, \mathrm{JB}, \mathrm{BC}$ and $\mathrm{PH}$ managed patients and collected clinical samples required for this study. JC, ChamP and TE critically reviewed and edited the manuscript. All authors read and approved the final manuscript.

\section{Ethics approval and consent to participate}

Ethical approval was given by the Khon Kaen University Ethics Committee (No. HE591377). The written consent was obtained from study participants. All procedures performed in studies involving human participants were in accordance with the ethical standards of the institutional and/or national research committee and with the 1964 Helsinki Declaration and its later amendments or comparable ethical standards. Informed consent was obtained from all individual participants included in the study, giving their authorization to access their clinical samples for research purpose.

\section{Consent for publication}

Not Applicable.

\section{Competing interests}

The authors declare that they have no conflict of interest.

\section{Publisher's Note}

Springer Nature remains neutral with regard to jurisdictional claims in published maps and institutional affiliations.

\section{Author details}

'Department of Microbiology, Faculty of Medicine, Khon Kaen University, Khon Kaen, Thailand. ${ }^{2}$ Department of Social Medicine, Khon Kaen Center Hospital, Khon Kaen, Thailand. ${ }^{3}$ Department of Animal Health Science, Faculty of Agro-Industrial Technology, Kalasin University, Kalasin, Thailand. ${ }^{4}$ Department of Obstetrics and Gynecology, Faculty of Medicine, Khon Kaen University, Khon Kaen, Thailand. ${ }^{5} \mathrm{HPV} \& \mathrm{EBV}$ and Carcinogenesis Research Group, Khon Kaen University, Khon Kaen, Thailand.

Received: 2 July 2018 Accepted: 23 September 2018

Published online: 11 October 2018

\section{References}

1. Fenton KA, Imrie J. Increasing rates of sexually transmitted diseases in homosexual men in Western Europe and the United States: why? Clin Infect Dis. 2005;19:311-31.

2. Martin JN, Osmond DH. Invited commentary: determining specific sexual practices associated with human herpesvirus 8 transmission. Am J Epidemiol. 2000;151:225-9.

3. O'mahony C, Law C, Gollnick H, Marini M. New patient-applied therapy for anogenital warts is rated favourably by patients. Int J STD AIDS. 2001;12: 565-70.

4. Trottier H, Franco EL. The epidemiology of genital human papillomavirus infection. Vaccine. 2006:24:S4-S15.

5. van der Loeff MFS, Mooij SH, Richel O, de Vries HJ, Prins JM. HPV and anal cancer in HIV-infected individuals: a review. Curr HIV/AIDS Rep. 2014;11:250-62.

6. Moscicki A-B, Palefsky JM. HPV in men: an update. J Low Genit Tract Dis. 2011;15:231.

7. Tsao SW, Tsang CM, Pang PS, Zhang G, Chen H, Lo KW. The biology of EBV infection in human epithelial cells. Semin Cancer Biol. 2012;22:137-43.

8. Odumade OA, Hogquist KA, Balfour HH. Progress and problems in understanding and managing primary Epstein-Barr virus infections. Clin Microbiol Rev. 2011;24:193-209.

9. Thompson MP, Kurzrock R. Epstein-Barr virus and cancer. Clin Cancer Res. 2004; 10:803-21.

10. Afonso LA, Moyses N, Alves G, Ornellas AA, Passos MRL, Oliveira LHS, et al. Prevalence of human papillomavirus and Epstein-Barr virus DNA in penile cancer cases from Brazil. Mem Inst Oswaldo Cruz. 2012;107:18-23.

11. Guimarães AGDP, JRd A, RVd A, CMd C, Galvão RS, Hada AL, et al. Coinfection of Epstein-Barr virus, cytomegalovirus, herpes simplex virus, human papillomavirus and anal intraepithelial neoplasia in HIV patients in Amazon, Brazil. J Coloproctol (Rio J). 2012;32:18-25.

12. Kahla S, Oueslati S, Achour M, Kochbati L, Chanoufi MB, Maalej M, et al. Correlation between ebv co-infection and HPV16 genome integrity in Tunisian cervical cancer patients. Braz J Microbiol. 2012;43:744-53.

13. Deng Z, Uehara T, Maeda H, Hasegawa M, Matayoshi S, Kiyuna A, et al. Epstein-Barr virus and human papillomavirus infections and genotype distribution in head and neck cancers. PLoS One. 2014;9:e113702

14. Polz-Gruszka D, Morshed K, Stec A, Polz-Dacewicz M. Prevalence of human papillomavirus (HPV) and Epstein-Barr virus (EBV) in oral and oropharyngeal squamous cell carcinoma in South-Eastern Poland. Infect Agent Cancer. 2015;10:37.

15. van Baarle D, Hovenkamp E, Dukers NH, Renwick N, Kersten MJ, Goudsmit J, et al. High prevalence of Epstein-Barr virus type 2 among homosexual men is caused by sexual transmission. J Infect Dis. 2000;181:2045-9.

16. Lama JR, Lucchetti A, Suárez L, Laguna-Torres VA, Guanira JV, Pun M, et al. Association of herpes simplex virus type 2 infection and syphilis with human immunodeficiency virus infection among men who have sex with men in Peru. J Infect Dis. 2006;194:1459-66.

17. Kortekangas-Savolainen O, Vuorinen T. Trends in herpes simplex virus type 1 and 2 infections among patients diagnosed with genital herpes in a Finnish sexually transmitted disease clinic, 1994-2002. Sex Transm Dis. 2007;34:37-40.

18. Ryder N, Jin F, Mcnulty AM, Grulich AE, Donovan B. Increasing role of herpes simplex virus type 1 in first-episode anogenital herpes in heterosexual women and younger men who have sex with men, 1992 2006. Sex Transm Infect. 2009;85:416-9. 
19. Lafferty WE, Downey L, Celum C, Wald A. Herpes simplex virus type 1 as a cause of genital herpes: impact on surveillance and prevention. J Infect Dis. 2000;181:1454-7.

20. Stamm WE, Handsfield HH, Rompalo AM, Ashley RL, Roberts PL, Corey L. The association between genital ulcer disease and acquisition of HIV infection in homosexual men. JAMA. 1988;260:1429-33.

21. Rautava J, Kuuskoski J, Syrjänen K, Grenman R, Syrjänen S. HPV genotypes and their prognostic significance in head and neck squamous cell carcinomas. J Clin Virol. 2012;53:116-20.

22. Turunen A, Hukkanen V, Nygårdas M, Kulmala J, Syrjänen S. The combined effects of irradiation and herpes simplex virus type 1 infection on an immortal gingival cell line. Virol J. 2014;11:125.

23. Budkaew J, Chumworathayi B, Pientong C, Ekalaksananan T. Conventional culture versus nucleic acid amplification tests for screening of urethral Neisseria gonorrhea infection among asymptomatic men who have sex with men. Pragmat Obs Res. 2017;8:167.

24. Budkaew J, Chumworathayi B, Peintong C, Ekalaksananan T. Endourethral swab versus urine collection for real-time PCR with TaqMan probe based detection of gonorrheal infection among men who have sex with men. J Med Assoc Thail. 2018;101:323-9.

25. Namwat $N$, Amimanan $P$, Loilome $W$, Jearanaikoon $P$, Sripa B, Bhudhisawasdi $V$, et al. Characterization of 5-fluorouracil-resistant cholangiocarcinoma cell lines. Chemotherapy. 2008;54:343-51.

26. Zehbe I, Wilander E, Delius H, Tommasino M. Human papillomavirus 16 E6 variants are more prevalent in invasive cervical carcinoma than the prototype. Cancer Res. 1998;58:829-33.

27. Tenorio A, Echevarría JE, Casasa I, Echevarría J, Tabarés E. Detection and typing of human herpesviruses by multiplex polymerase chain reaction. J Virol Methods. 1993:44:261-9.

28. Panagiotakis SH, Soufla G, Baritaki S, Sourvinos G, Passam A, Zagoreos I, et al. Concurrent CMV and EBV DNAemia is significantly correlated with a delay in the response to HAART in treatment-naive HIV type 1-positive patients. AIDS Res Hum Retrovir. 2007;23:10-8.

29. van den Brule AJ, Pol R, Fransen-Daalmeijer N, Schouls LM, Meijer CJ, Snijders PJ. GP5+/6+ PCR followed by reverse line blot analysis enables rapid and high-throughput identification of human papillomavirus genotypes. J Clin Microbiol. 2002;40:779-87.

30. Lowhagen G, Bergbrant I, Bergstrom T, Voog E. PCR detection of EpsteinBarr virus, herpes simplex virus and human papillomavirus from the anal mucosa in HIV-seropositive and HIV-seronegative homosexual men. Int J STD AIDS. 1999;10:615-8.

31. Naeher $\mathrm{H}$, Lenhard B, Wilms J, Nickel P. Detection of Epstein-Barr virus DNA in anal scrapings from HIV-positive homosexual men. Arch Dermatol Res. 1995;287:608-11.

32. Ferbas J, Rahman MA, Kingsley LA, Armstrong JA, Ho M, Zhou SY, et al. Frequent oropharyngeal shedding of Epstein-Barr virus in homosexual men during early HIV infection. AIDS. 1992;6:1273-8

33. Diaz-Mitoma F, Ruiz A, Flowerdew G, Houston S, Romanowski B, Kovithavongs T, et al. High levels of Epstein-Barr virus in the oropharynx: a predictor of disease progression in human immunodeficiency virus infection. J Med Virol. 1990:31:69-75.

34. Gianella S, Smith DM, Vargas MV, Little SJ, Richman DD, Daar ES, et al. Shedding of HIV and human herpesviruses in the semen of effectively treated HIV-1-infected men who have sex with men. Clin Infect Dis. 2013;57:441-7.

35. Gianella S, Ginocchio CC, Daar ES, Dube MP, Morris SR. Genital Epstein Barr virus is associated with higher prevalence and persistence of anal human papillomavirus in HIV-infected men on antiretroviral therapy. BMC Infect Dis. 2016;16:24.

36. Kaspersen MD, Höllsberg P. Seminal shedding of human herpesviruses. Virol J. 2013;10:226

37. Van Der Snoek EM, Niesters HG, Mulder PG, Van Doornum GJ, Osterhaus $A D$, van der Meijden WI. Human papillomavirus infection in men who have sex with men participating in a Dutch gay-cohort study. Sex Transm Dis. 2003:30:639-44.

38. Breese PL, Judson FN, Penley KA, Douglas JM Jr. Anal human papillomavirus infection among homosexual and bisexual men: prevalence of type-specific infection and association with human immunodeficiency virus. Sex Transm Dis. 1995;22:7-14.

39. Hu Y, Qian H-Z, Sun J, Gao L, Yin L, Li X, et al. Anal human papillomavirus infection among HIV-infected and uninfected men who have sex with men in Beijing, China. J Acquir Immune Defic Syndr. 2013;64:103.
40. Ucciferri C, Tamburro M, Falasca K, Sammarco ML, Ripabelli G, Vecchiet J. Prevalence of anal, oral, penile and urethral human papillomavirus in HIV infected and HIV uninfected men who have sex with men. J Med Virol. 2018:90:358-66.

41. Read TR, Hocking JS, Vodstrcil LA, Tabrizi SN, McCullough MJ, Grulich AE, et al. Oral human papillomavirus in men having sex with men: risk-factors and sampling. PLoS One. 2012;7:e49324.

42. Van Rijn VM, Mooij SH, Mollers M, Snijders PJ, Speksnijder AG, King AJ, et al. Anal, penile, and oral high-risk HPV infections and HPV seropositivity in HIVpositive and HIV-negative men who have sex with men. PLoS One. 2014;9: e92208.

43. Quinn R, Salvatierra J, Solari V, Calderon M, Ton TG, Zunt JR. Human papillomavirus infection in men who have sex with men in Lima, Peru. AIDS Res Hum Retrovir. 2012;28:1734-8.

44. Damay A, Fabre J, Costes V, Didelot J-M, Didelot M-N, Boulle N, et al. Human papillomavirus (HPV) prevalence and type distribution, and HPVassociated cytological abnormalities in anal specimens from men infected with HIV who have sex with men. J Med Virol. 2010;82:592-6.

45. Sammarco ML, Ucciferri C, Tamburro M, Falasca K, Ripabelli G, Vecchiet J. High prevalence of human papillomavirus type 58 in HIV infected men who have sex with men: a preliminary report in Central Italy. J Med Virol. 2016;88:911-4.

46. Müller EE, Rebe K, Chirwa TF, Struthers H, Mclntyre J, Lewis DA. The prevalence of human papillomavirus infections and associated risk factors in men-who-have-sex-with-men in Cape Town, South Africa. BMC Infect Dis. 2016;16:440

47. Hill C, McKinney E, Lowndes C, Munro H, Murphy G, Parry J, et al. Epidemiology of herpes simplex virus types 2 and 1 amongst men who have sex with men attending sexual health clinics in England and Wales: implications for HIV prevention and management. Eur Secur. 2009;14:19418.

48. Russell DB, Tabrizi SN, Russell JM, Garland SM. Seroprevalence of herpes simplex virus types 1 and 2 in HIV-infected and uninfected homosexual men in a primary care setting. J Clin Virol. 2001;22:305-13.

49. Kapranos N, Petrakou E, Anastasiadou C, Kotronias D. Detection of herpes simplex virus, cytomegalovirus, and Epstein-Barr virus in the semen of men attending an infertility clinic. Fertil Steril. 2003:79:1566-70.

50. Mäki J, Paavilainen H, Kero K, Hukkanen V, Syrjänen S. Herpes simplex and human papilloma virus coinfections in oral mucosa of men-a 6-year follow-up study. J Med Virol. 2018;90:564-70.

51. Kiviat NB, Critchlow CW, Hawes SE, Kuypers J, Surawicz C, Goldbaum G, et al. Determinants of human immunodeficiency virus DNA and RNA shedding in the anal-rectal canal of homosexual men. J Infect Dis. 1998;177:571-8.

52. Aggarwal $P$, Bhattar S, Sahani SK, Bhalla P, Garg VK. Sexually transmitted infections and HIV in self reporting men who have sex with men: a twoyear study from India. J Infect Public Health. 2016;9:564-70.

53. Parisi SG, Cruciani M, Scaggiante R, Boldrin C, Andreis S, Dal Bello F, et al. Anal and oral human papillomavirus (HPV) infection in HIV-infected subjects in northern Italy: a longitudinal cohort study among men who have sex with men. BMC Infect Dis. 2011:11:150.

54. McDonald JD. Measuring personality constructs: the advantages and disadvantages of self-reports, informant reports and behavioural assessments. Enquire. 2008;1:1-19.

Ready to submit your research? Choose BMC and benefit from:

- fast, convenient online submission

- thorough peer review by experienced researchers in your field

- rapid publication on acceptance

- support for research data, including large and complex data types

- gold Open Access which fosters wider collaboration and increased citations

- maximum visibility for your research: over $100 \mathrm{M}$ website views per year

At $\mathrm{BMC}$, research is always in progress.

Learn more biomedcentral.com/submissions 